\title{
Small bowel obstruction secondary to ileal endometriosis: multisection computer tomography evaluation
}

\author{
C. L. Fernández-Rey, S. A. Álvarez-González, P. Díaz-Solís, A. Blanco-González and S. Costilla-García \\ Services of Radiodiagnosis and General Surgery. Hospital Universitario Central de Asturias. Oviedo, Asturias. Spain
}

Approximately 10 to $15 \%$ of pre-menopausal women are affected by endometriosis, which in rare cases can cause intestinal obstruction (1). The presence of ectopic endometriotic tissue in the loops of the small bowel affects the serosa (visceral peritoneum) and muscularis propria, but never penetrates the mucosa (2). Fibrosis and secondary adhesions are the major causes of obstruction (2). Ileal involvement is uncommon and usually affects the terminal ileum within $10 \mathrm{~cm}$ of the ileocecal valve (3). Intestinal endometriosis should be suspected in cases of young nulliparous women with abdominal or pelvic pain $(3,4)$.

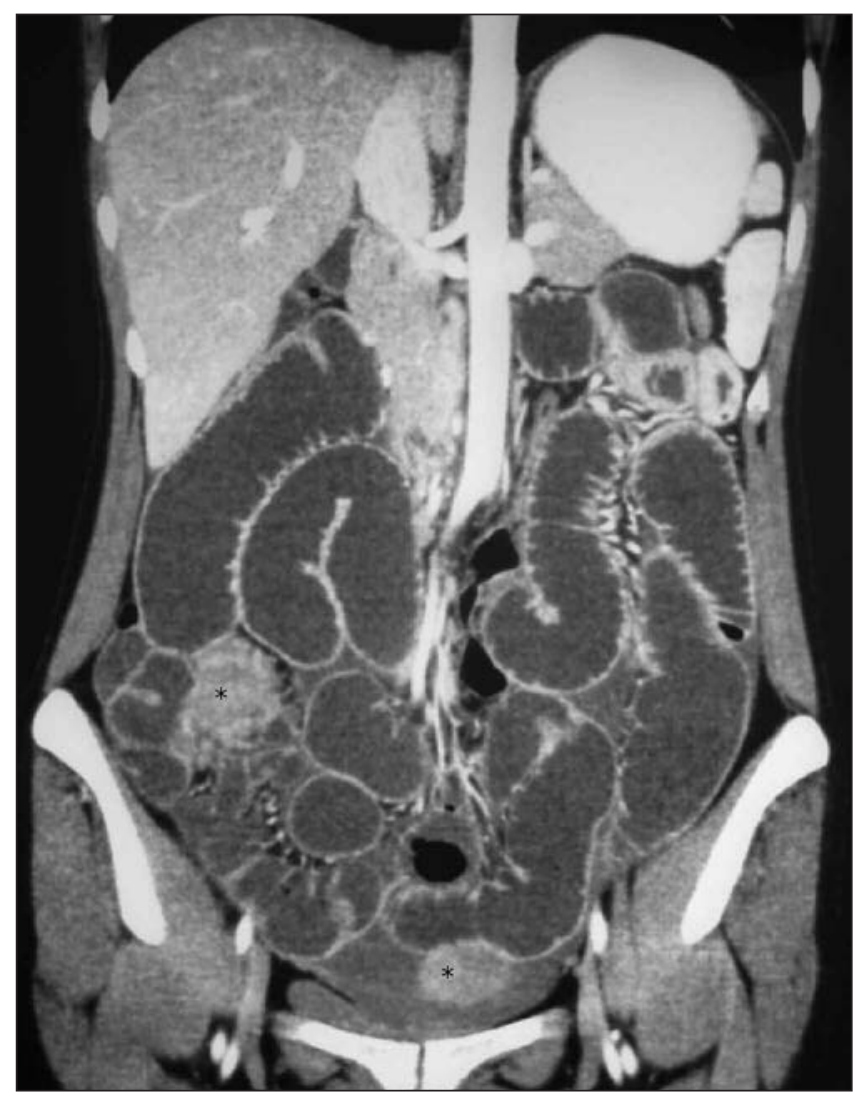

Fig. 1. MIP (Maximun Intensity Projection) of a coronal contrast-enhanced CT image showing the presence of two enhanced peritoneal nodules $\left.{ }^{*}\right)$ and dilatation of the small bowel. Imagen coronal MIP (maximun intensity projection) de TC con contraste que demuestra la presencia de dos nódulos peritoneales hipercaptantes $\left(^{*}\right.$ y dilatación de asas de intestino delgado.
Imaging diagnosis is difficult. However, multisection computer tomography (CT) provides high spatial resolution and multiplanar reformation images, which can be very demonstrative and characteristic.

\section{CASE REPORT}

We report the case of a 22-year-old woman without any significant prior medical history who presented with abdominal pain and high leukocytosis. A contrast-enhanced

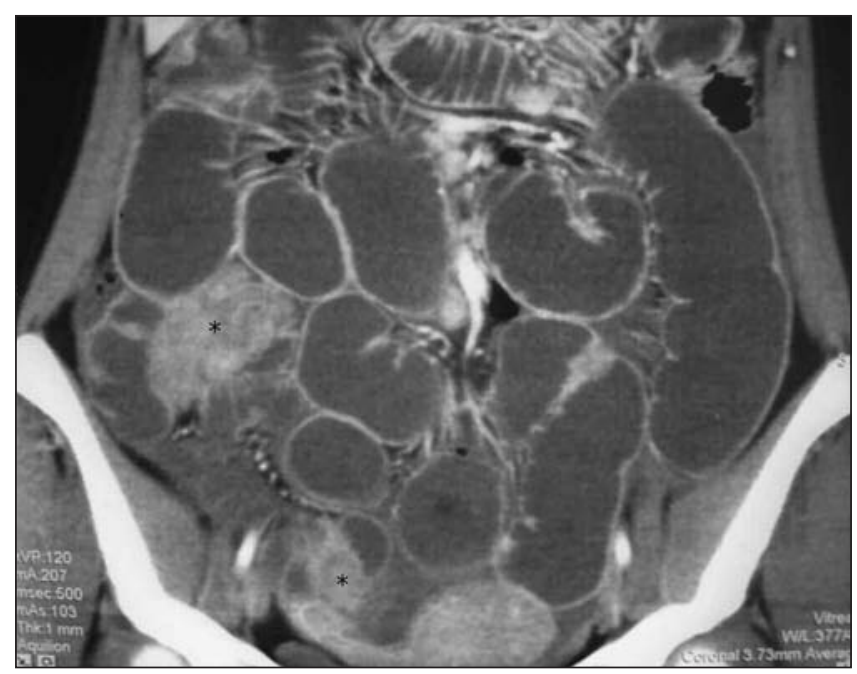

Fig. 2. MIP from a coronal contrast-enhanced CT image showing a detailed endometriotic implant in the right ileo-cecal area $\left(^{*}\right)$ and a second focus of endometriosis in the right annexial region $(*)$.

Imagen coronal MIP de TC con contraste que muestra con detalle un implante de endometriosis en el área íleo-cecal derecha (*) y un segundo foco de endometriosis en la región anexial derecha $\left(^{*}\right)$. 


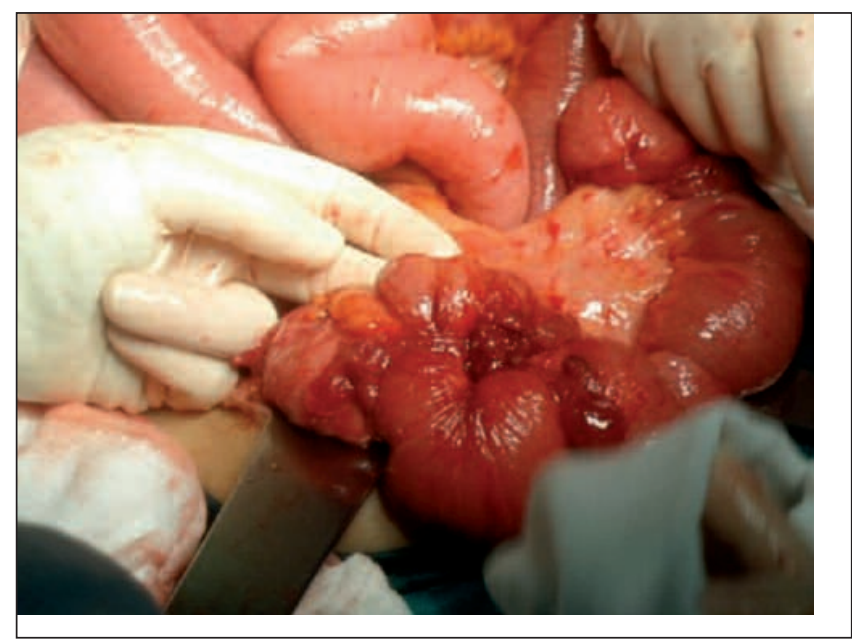

Fig. 3. Image demonstrating the existence of endometriotic peritoneal implants during the surgical intervention.

Imagen que demuestra la existencia de implantes de endometriosis peritoneales durante la intervención quirúrgica.

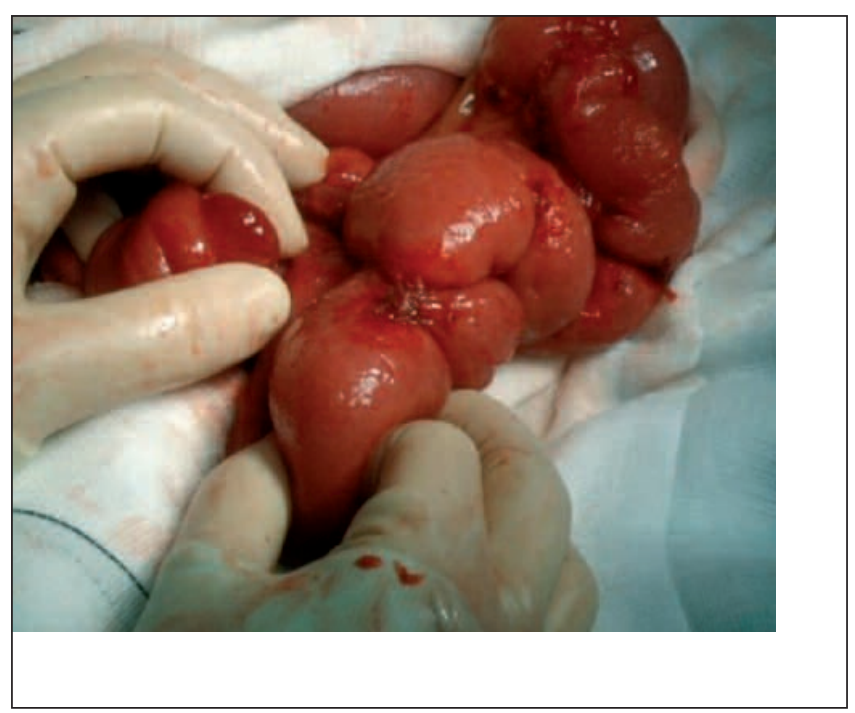

Fig. 4. Endometriotic implant in the visceral peritoneum, which envelops the small bowel with adhesions between loops.

Foco de endometriosis en el peritoneo visceral que envuelve el intestino delgado con adherencias entre las asas.

multisection CT was performed, which revealed significant small-bowel dilatation and multiple nodular contrast-enhanced lesions located in the pelvis (Fig. 1). One of the lesions affected the right annexial region while the remaining lesions were located in the visceral peritoneum involving the small bowel. The largest lesion measured approximately $3 \mathrm{~cm}$ in diameter and involved the appendiceal region and terminal ileum, this being the transition point of the obstruction(Fig. 2). The diagnosis after CT examination was small-bowel obstruction secondary to intestinal endometriosis. Surgery confirmed the CT findings, identifying multiple endometriotic implants in the serosa of the small bowel, especially at the level of the terminal ileum (Figs. 3 and 4). A segment of terminal ileum and the appendix were resected. Histopathological examination of the resected specimen revealed endometriotic implants involving the appendix and terminal ileum.

\section{REFERENCES}

1. Ruiz-Tovar J, Pina Hernández JD, Lobo Martínez E, et al. Endometriosis intestinal. Rev Esp Enferm Dig 2007; 99(12): 732-3.

2. Martimbeau PW, Pratt JH, Gaffey TA. Small-bowel obstruction secondary to endometriosis. Mayo Clin Proc 1975; 50(5): 239-43.

3. Scarmato VJ, Levine MS, Herlinger H, Wickstrom M, Furth EE, Tureck RW. Ileal endometriosis: radiographic findings in five cases. Radiology 2000; 214: 509-12.

4. Woodward P J, Sohaey R, Mezzetti TP. Endometriosis: radiologic-pathologic correlation. Radiographics 2001; 21: 193-216. 